\title{
Supplementary Table and Figures
}

Table S1. Crystallographic parameters of oxides and metals as reference materials.

Linear and volumetric thermal expansion coefficients are also listed.

List of references;

Kuriyama, M. H., Sukeaki X-ray Measurement of Scattering Factors of Manganese and Oxygen Atoms in Manganous Oxide. Journal of the Physical Society of Japan 1962, 17, (6), 1022.

Suzuki, I. O., Shinichi; Seya, Kiyoshi, Thermal expansion of single-crystal manganosite. Journal of Physics of the Earth 1979, 27, (1), 63-69.

Toussaint, C., A high-temperature X-ray diffraction study of the NiO-Li2O system. Journal of Applied Crystallography 1971, 4, (4), 293-297.

Rougier, A.; Gravereau, P.; Delmas, C., Optimization of the composition of the Li1-zNi1+zO2 electrode materials: Structural, magnetic, and electrochemical studies. Journal of the Electrochemical Society 1996, 143, (4), 1168-1175. 
Armstrong, A. R.; Bruce, P. G., Synthesis of layered LiMnO2 as an electrode for rechargeable lithium batteries. Nature 1996, 381, (6582), 499-500.

Gillot, B.; Baudour, J. L.; Bouree, F.; Metz, R.; Legros, R.; Rousset, A., Ionic Configuration and Cation Distribution in Cubic Nickel Manganite Spinels Nixmn3-Xo4(0.57-Less-Than-X-Less-Than-1) in Relation with Thermal Histories. Solid State Ionics 1992, 58, (1-2), 155-161.

Brabers, V. A. M.; Terhell, J., Electrical-Conductivity and Cation Valencies in Nickel Manganite. Physica Status Solidi a-Applied Research 1982, 69, (1), 325-332.

Ariyoshi, K.; Iwakoshi, Y.; Nakayama, N.; Ohzuku, T., Topotactic two-phase reactions of $\mathrm{Li}[\mathrm{Ni1} / 2 \mathrm{Mn} 3 / 2] \mathrm{O}-4(\mathrm{P} 4(3) 32)$ in nonaqueous lithium cells. Journal of the Electrochemical Society 2004, 151, (2), A296-A303.

Ohzuku, T.; Kitagawa, M.; Hirai, T., Electrochemistry of Manganese-Dioxide in Lithium Nonaqueous Cell .3. X-Ray Diffractional Study on the Reduction of Spinel-Related Manganese-Dioxide. Journal of the Electrochemical Society 1990, 137, (3), 769-775. 
Owen, E. A. Y., E. L., X-ray measurement of the thermal expansion of pure nickel. Philosophical Magazine 1936, 21, 809-19.

Gazzara, C. P.; Middleton, R. M.; Weiss, R. J.; Hall, E. O., A refinement of the parameters of [alpha]-manganese. Acta Crystallographica 1967, 22, (6), 859-862.

Thermal Properties of Metals. ASM International: Ohio, 2003.

Figure S1. The change in lithium-oxygen and metal-oxygen bond lengths on the pristine sample as a function of the temperature in the range of 25 to $600{ }^{\circ} \mathrm{C}$.

Figure S2. The change in the unit cell volume on the pristine $\mathrm{LiNi}_{0.5} \mathrm{Mn}_{0.5} \mathrm{O}_{2}$ sample as a function of the temperature in the range of 25 to $600{ }^{\circ} \mathrm{C}$. Volumetric thermal expansion coefficient $\beta$ is calculated to be $5.64 \times 10^{-5}{ }^{\circ} \mathrm{C}^{-1}$.

Figure S3. Structural analysis by the Rietveld method obtained (a) at 200 and (b) $275{ }^{\circ} \mathrm{C}$ for the charged $\mathrm{Li}_{0.2} \mathrm{Ni}_{0.5} \mathrm{Mn}_{0.5} \mathrm{O}_{2}$ and (c) at $275{ }^{\circ} \mathrm{C}$ for the discharged $\mathrm{Li}_{0.9} \mathrm{Ni}_{0.5} \mathrm{Mn}_{0.5} \mathrm{O}_{2}$. The values of $\mathrm{R}_{\mathrm{wp}}$ were (a) 18.6, (b) 27.6, and (c) 14.4. Dots 
and solid lines show observed and calculated values, respectively, and the difference is also shown at the figure bottom.

Figure S4. Thermogravimetric (TG) curves of the pristine $\mathrm{LiNi}_{0.5} \mathrm{Mn}_{0.5} \mathrm{O}_{2}$ and $\mathrm{LiNi}_{0.5} \mathrm{Mn}_{0.5} \mathrm{O}_{2}$ electrode consisting of the sample powder, carbon, and binder under nitrogen gas flow in the temperature range of $25-600{ }^{\circ} \mathrm{C}$.

Figure S5. A scheme on the thermal degradation process for $\mathrm{Li}_{0.3} \mathrm{NiO}_{2}{ }^{1}$ 


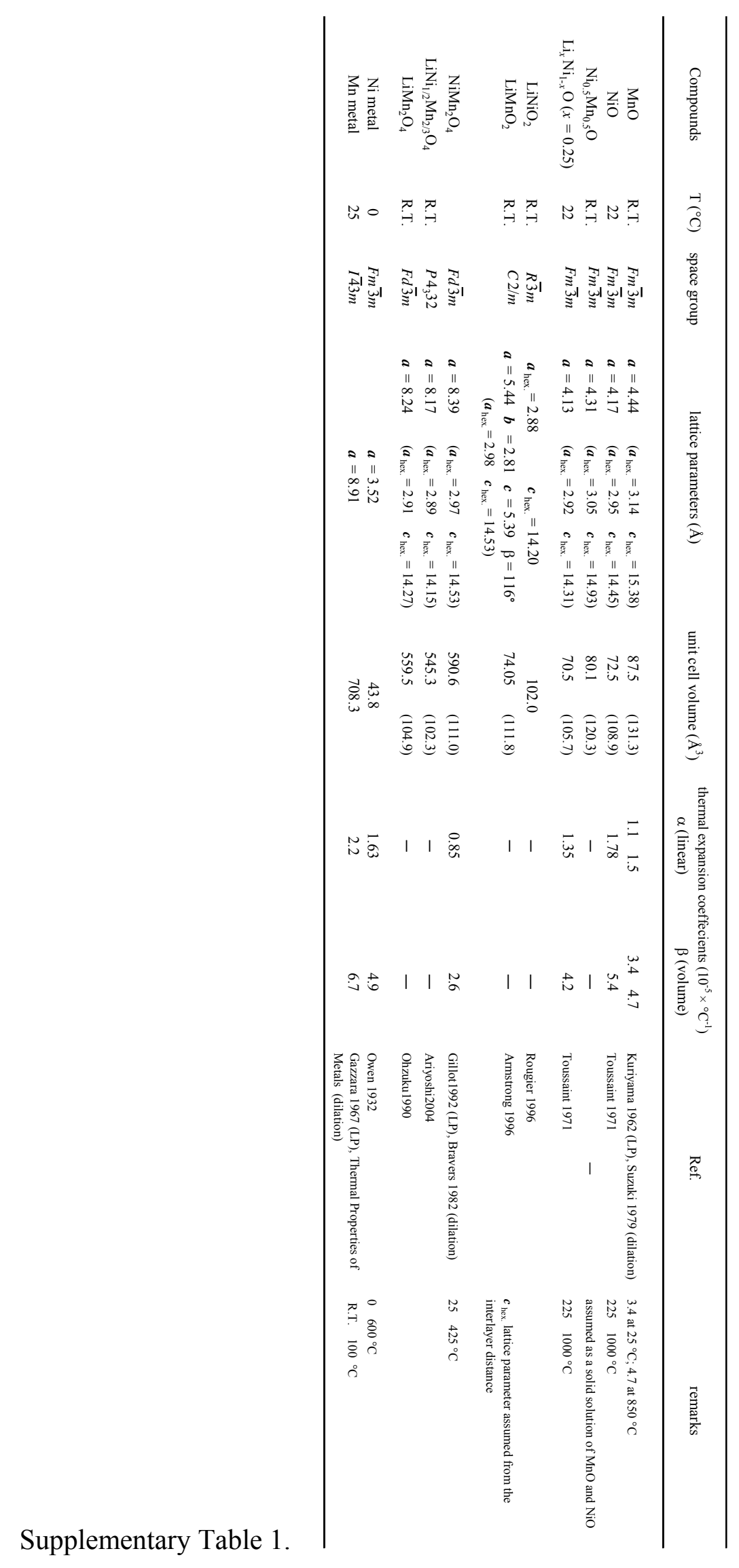




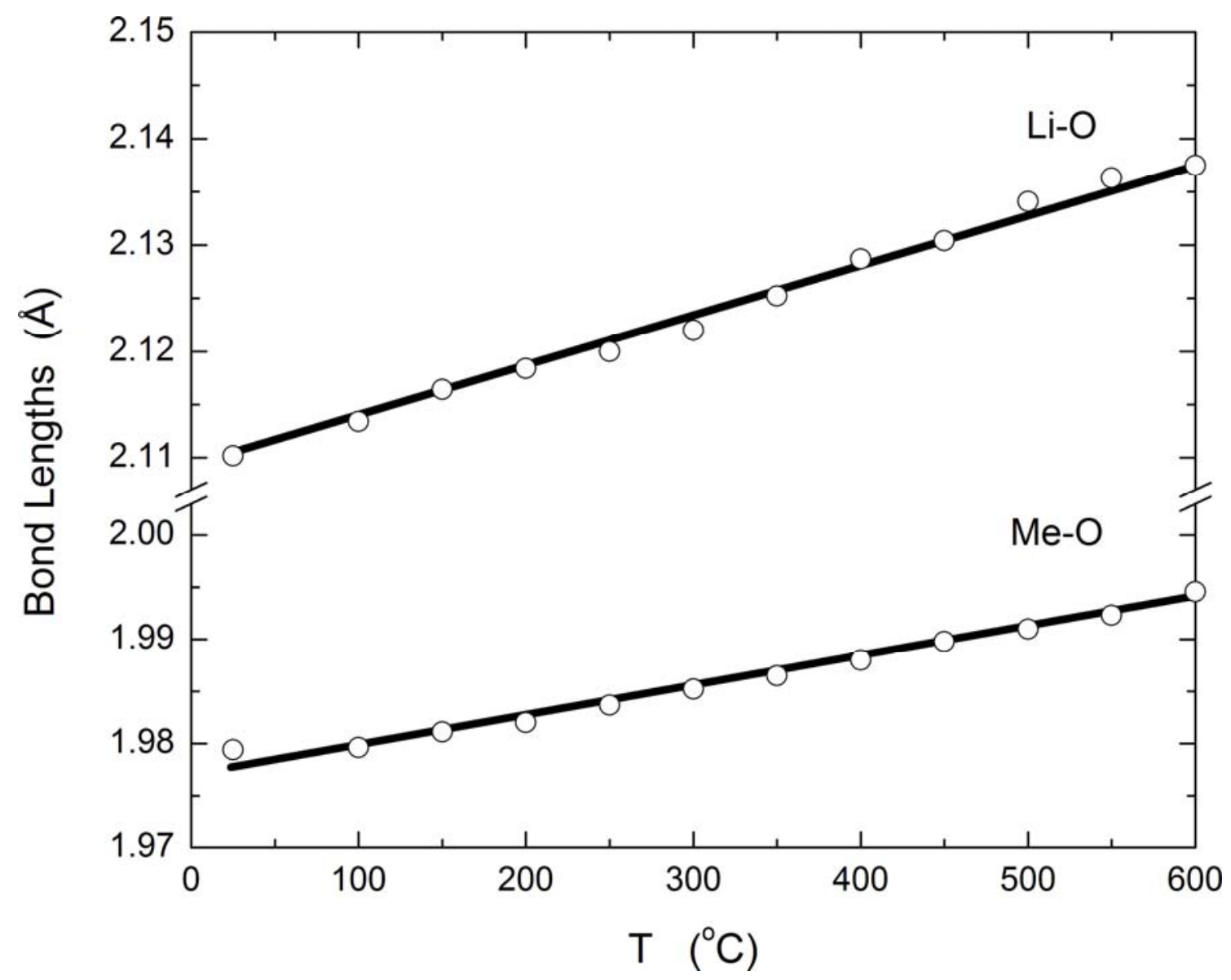

Supplementary Figure S1 


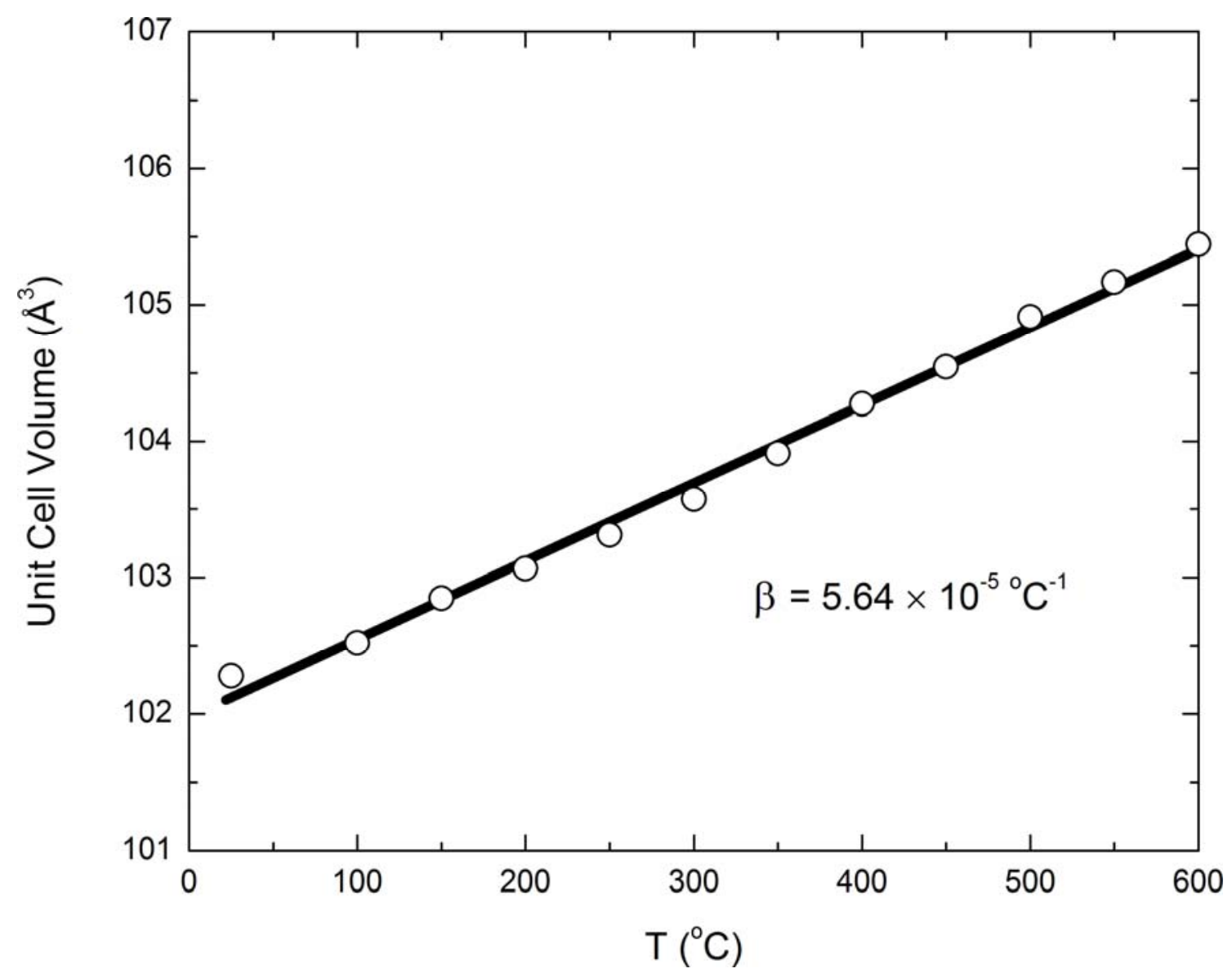

Supplementary Figure S2 

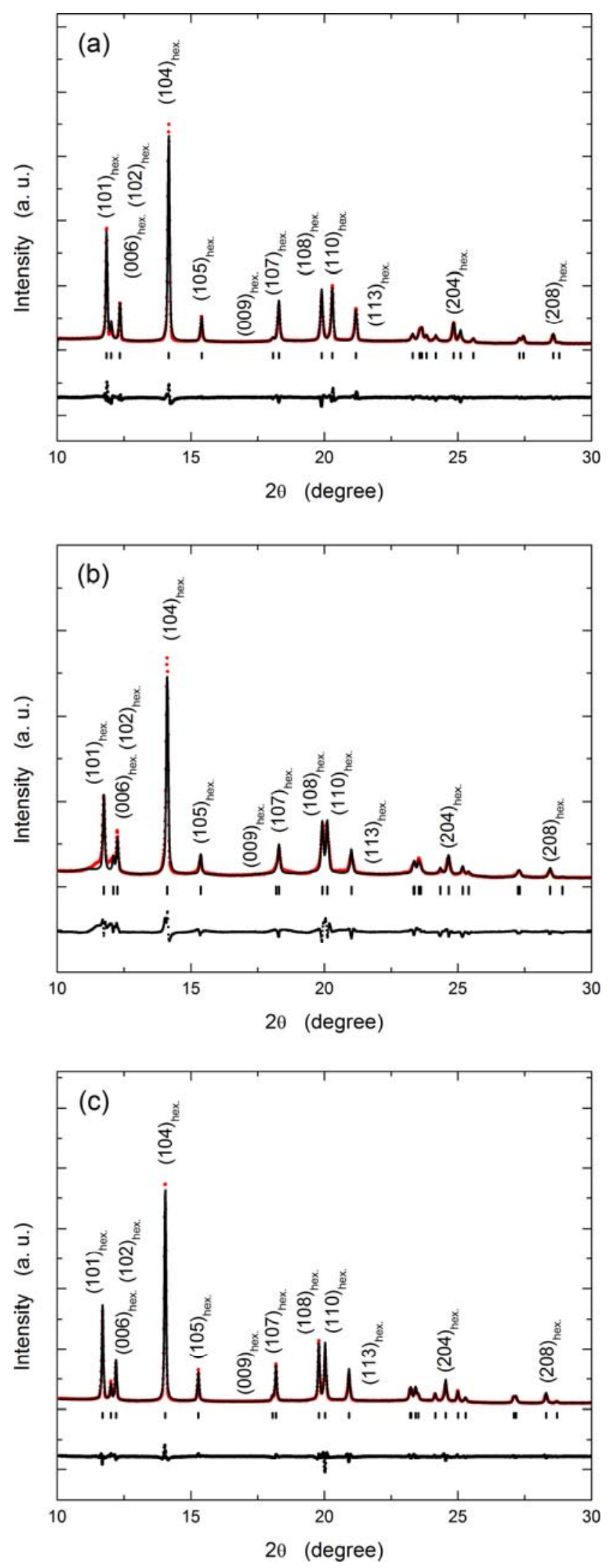

Supplementary Figure S3 


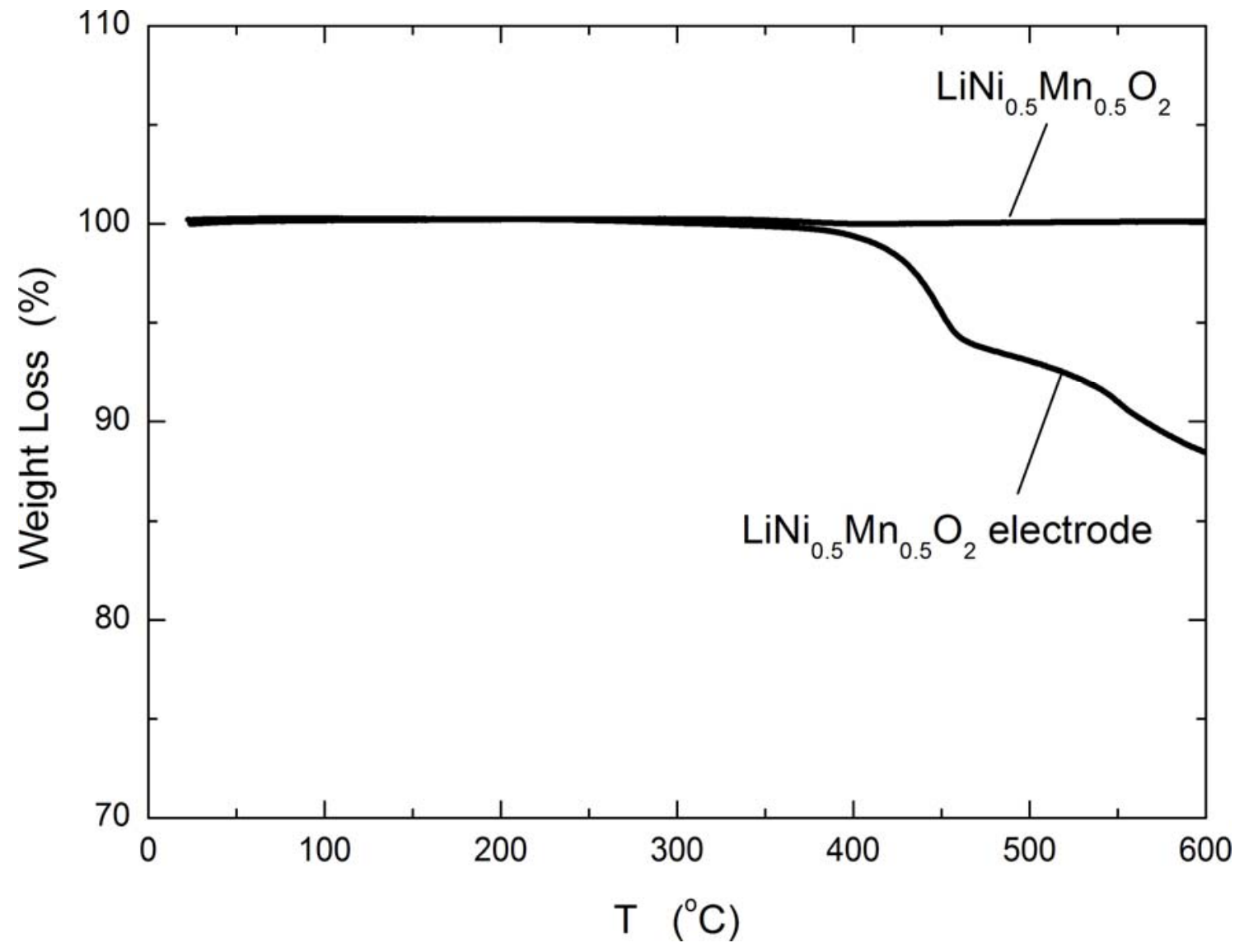

Supplementary Figure S4 


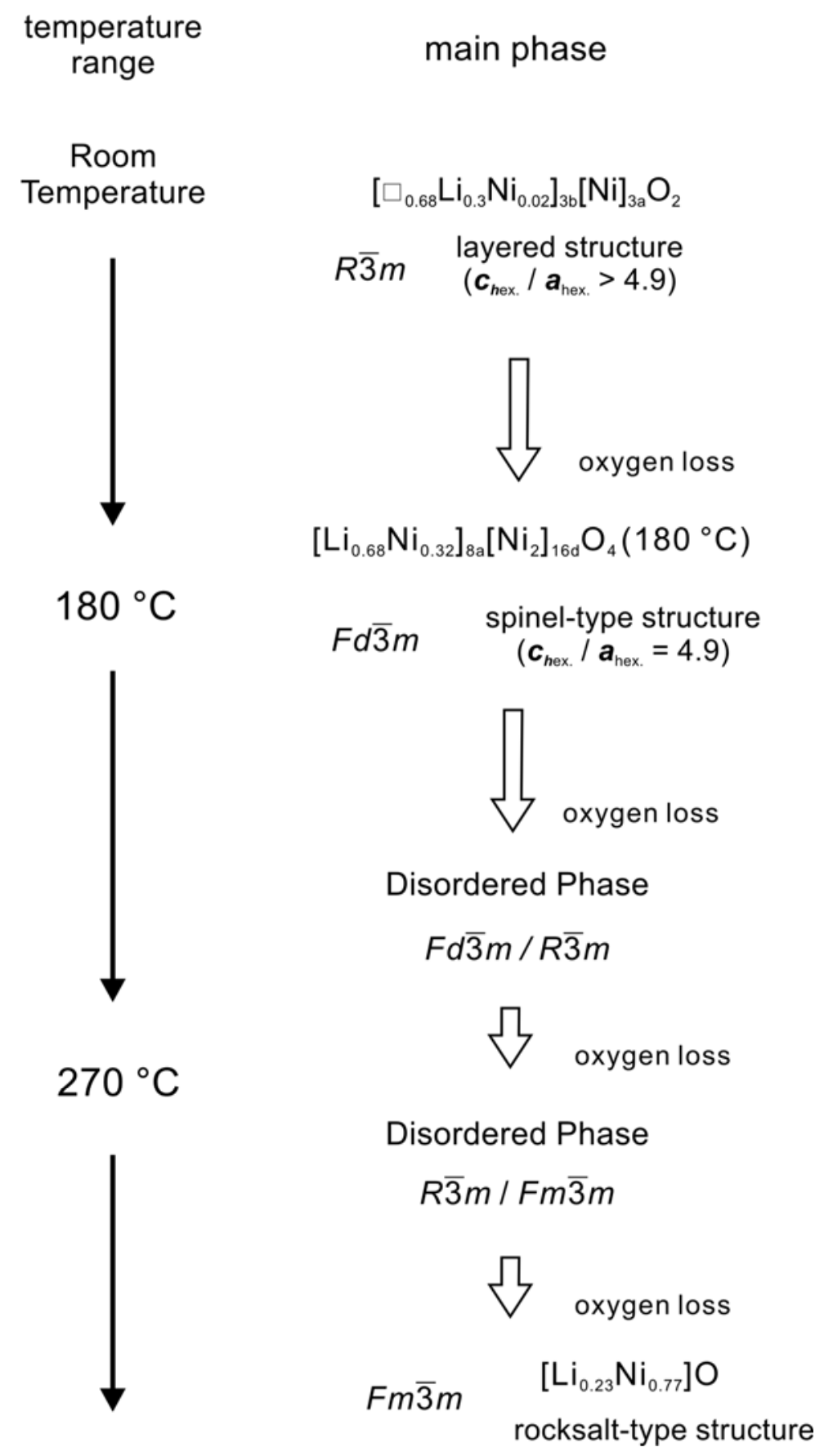

Supplementary Figure S5 